\title{
Family Planning as A Determining Factor in Preference to Traditional Birth Attendants (TBAs) Among Somali Community in Dadaab Refugee Camps, Kenya
}

\author{
Newton Kahumbi Maina, Josephine Gitome, Jennifer Bagelman, Muthoni Mainah, \\ Jacqueline M. Kituku, Teresa Mwoma and Priscilla Ndegwa
}

\begin{abstract}
Statement of Problem: Family planning is a determining factor in the maternal health care choices for Somali pregnant mothers in Dadaab Refugee camps. Research has revealed that during delivery, the Somali mothers prefer the services of Traditional Birth Attendants (TBAs) to those of midwives in hospitals. The preference for TBAs is borne of the belief that when women deliver in hospitals, they could be subjected to family planning against their will. The contention is that Islam and socio-cultural practices of the Somali community do not advocate family planning. The purpose of this paper is to discuss Islam's position on family planning in order to explain the response of the Somalis of Dadaab refugee camps on family planning. Methodology \& Theoretical orientation: The paper is derived from a qualitative study that involved snowball sampling, in-depth interviews and focus group discussions (FGDs). These methods brought out family planning as a determining factor in the mother's choice of TBAs as opposed to hospital midwives in Dadaab Refugee camps. Findings: Any discourse on Islam and family planning offers two perspectives: proponents of family planning and opponents of family planning. Both perspectives use the texts of the Qur'an and Hadith (traditions) and different interpretations to justify and support their respective positions and opinions. Through primary and secondary sources, the paper interrogates both perspectives of family planning in Islam. Conclusion \& Significance: It is concluded that the Somalis' belief on family planning is informed by the two perspectives of family planning, but the opponents' perspective holds sway. This determines the preference for TBAs for fear that mothers who deliver in hospitals could be subjected to family planning contraceptives. Recommendation: there is need to educate the community further on Islamic teachings on family planning; and more sensitization conducted on the benefits of child spacing.
\end{abstract}

Keywords - al- 'Azl (coitus interruptus or withdrawal), Family planning, Hadith, Islam, Prophet Muhammad, Qur'an, Somali, Traditional Birth Attendants (TBAs).

\section{INTRODUCTION}

A discourse on Islam and family planning brings out two perspectives: proponents and opponents of family planning. Both the proponents and opponents of family planning in Islam use the texts of the Qur'an, Hadith (traditions - sayings of Prophet Muhammad), I'jma (consensus of the Muslim jurists) and al-Qiyas (analogical deductions) to justify their positions and support their respective opinions. This paper interrogates both perspectives of proponents and opponents of family planning in Islam by using both primary and secondary data. Primary data is derived from oral response and Islamic sources: Qur'an and Hadith. Secondary data is from literature on family planning. The paper concludes that the Somali community's belief and practice of family planning with its attendant preferences for TBAs is informed by the two perspectives of family planning in Islam.

\section{The Context of the Debate}

The main sources of Muslim guidance and conduct are the Qur'an and Hadith (Sunna). Other complementary sources are I'jma and al-Qiyas. As the primary sources of religious authority, Muslims turn to the Qur'an and Hadith for answers to questions about their daily life and conduct, before taking recourse to interpretations from I'jma and al-Qiyas. There is no explicit verse in the Qur'an that forbids Muslims from family planning or using various methods of contraception to space pregnancies or limit the number of children [1]. Scholars have interpreted the silence of the Qur'an on family planning to mean that the holy text does not prohibit its practice [2]. In addition, the implicit approval for al-azl lends credence to Islam's support for family planning. Conversely, some Qur'anic verses [3] that prohibit infanticide could be interpreted to discourage Muslims from practicing family planning [4]. Hence the debate on Islam's position on family planning and different interpretations by scholars. The debate brings about two varied perspectives: the proponents of family planning and opponents of family planning. Both the proponents and opponents of family planning use the Qur'an and Hadith texts, and interpretations of I'jma and al-Qiyas to support their arguments. The two perspectives generally determine the response of Muslim communities to family planning and use of contraceptives. This is because, largely Muslims across sects, schools of thoughts, cultures and regions rely on the Qur'an, Hadith, and interpretations of Islamic scholars on a variety of issues, of which family planning is no exception. The next section of the paper

(email: dr.muthonimainah@gmail.com)

Jacqueline Kituku, Kenyatta University, Kenya.

(email: jackkituku@gmail.com)

Teresa Mwoma, Kenyatta University, Kenya.

(email: mwoma.teresa@ku.ac.ke)

Priscilla Ndegwa Kenyatta University, Kenya.

(email: priscyndegwa@gmail.com) 
examines the perspectives of both the proponents and opponents of family planning in Islam.

\section{PRoponents of FAmily PlanNing In ISLAM}

In this section, we shall discuss the perspective of the proponents of family planning. The Qur'an is not explicit on family planning, i.e. either in favor or against the use of contraceptives. However, proponents of family planning quote Qur'an 2:233 ${ }^{1}$ on breast feeding and weaning to support their claim on family planning. They conclude that the instruction in this verse implies a minimal child spacing period of thirty months; that is, two years of weaning and a minimum of six months of pregnancy that can produce alive

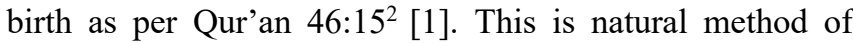
family planning whose argument is further buttressed by the Hadith where the Prophet (Peace be upon him - Pbuh) warns women against getting pregnant during breast feeding, calling it ghaylah (assault on the child) ${ }^{3}$ [1],[4]. Scholars and proponents of family planning interpret the Qur'an's approval of two years of breast-feeding and the Prophet's sanction against pregnancy during lactation as a validation for child spacing [5]. In support of breastfeeding for child spacing, Imam Al-Ghazali, an $11^{\text {th }}$ century foremost theologian, jurist and philosopher of Islam opined, that a mother must breastfeed each child for up to two years, while she is lactating. To avoid another pregnancy, couples should practice birth control methods [4].

It is difficult for a couple in monogamous marriage, and for a woman in a polygynous marriage to abstain from sex for three years. While Islam permits polygyny ${ }^{4}$ for men who can marry up to four wives, and therefore could turn to the other wives for sexual gratification, the woman may not have the same recourse. Yet the teachings of Qur'an ${ }^{5}$ and Hadith $^{6}$ [6] are categorical that Allah does not desire difficulty for His people. According to the proponents of family planning, the alternative would be contraception since the Qur'an apparently upholds natural family planning.

Apart from the two verses on breastfeeding and weaning discussed above, the Qur'an is generally silent on the use of contraceptives and family planning [7]. Therefore, Muslims have to take recourse to the Hadith, the second primary source of Muslim conduct. The Qur'an instructs Muslims to follow the Prophet (Pbuh) in all his actions and sayings ${ }^{7}$.

The proponents of family planning refer to the three ahadith (plural of hadith) that approved al- 'Azl verbally or

\footnotetext{
${ }^{1}$ This verse says: "The mothers shall give suck to their offspring for two whole years".

${ }^{2}$ The verse says: "The carrying of the (child) to his weaning is (a period of) of thirty months.

${ }^{3}$ The hadith, cited from Sunan Abu Dawud is reported by Asma bint Zaid ibn al Sakn, who said: "I heard the Prophet (Pbuh) say: "Do not kill your children unconsciously, for al-ghaylah will have in the future the same effect as when a horseman is overtaken (by an opponent) and thrown of his horse.

${ }^{4}$ Qur'an 4:3: "if ye fear that you shall not be able to deal justly with the orphans, marry women of your choice, two or three or four; but if ye fear that ye shall not be able to deal justly (with them), then only one, or (a captive) that your right hand possesses".

${ }^{5}$ Qur'an 2:185 says: "Allah intends every facility for you; He does not want to put you to difficulties"; Qur'an 22:78 says: "He has chosen you and has imposed no difficulties on you in religion. Qur'an 4:28 says: "Allah doth wish to lighten your (difficulties): for man was created weak (in flesh).

${ }^{6}$ According to the Hadith, the Prophet is reported to have said: "This religion of Islam is a religion of ease, free from narrow restrictions; anyone
}

implicitly. It is worthwhile to reproduce these ahadith. In a hadith recorded in Sahih Muslim ${ }^{8}$ and reported by Jabir:

A man came to the Prophet (Pbuh) and said, "I have a mate who serves us and waters our palm trees. I have sexual relations with her but do not like her to fall pregnant". The Prophet (Pbuh) said:' Practice al- 'Azl with her if you so wish, for she shall receive what Allah predestined her. After some time, the man came back and said: "my mate has conceived". The Prophet (Pbuh) said: "I informed you that what is predestined will befall her" [6].

Another version of the above hadith is recorded in Sahih al-Bukhari in which Jabir reports: "We used to have recourse to al- 'Azl during the days of the Prophet while the Qur'an was being revealed. He came to know of it but he did not prevent us from doing so" [4].

In another hadith, the Prophet (Pbuh) alluded to al- 'Azl tacitly:

Abu Sa'id al-Kudri (RA - Radi Allahu 'Anhu -May Allah be pleased with him) narrated that during the Battle of Hunayn, they wanted to practice al- 'Azl. They consulted the Prophet (Pbuh) who said, "Do as you wish! Whatever Allah has ordained will be, not all the semen produce a child [2].

The proponents of family planning also note that, al- 'Azl was practiced during the time of the Prophet (Pbuh) by his Companions $^{9}$ and he gave tacit approval. In a hadith recorded in Sahih Muslim:

Abu Sa'id al-Kudri (RA) reported: The Prophet (Pbuh) was questioned regarding al- 'Azl and he said, "not out of all the semen a child is formed, and if Allah willed to create something nothing would stop Him from doing so [6].

From these ahadith, it is evident that the Prophet (Pbuh) knew about al- 'Azl, permitted and did not prohibit it [1], [4]. Indeed, ten Companions of the Prophet (Pbuh) confirm the permissibility and legality of al- 'Azl [7] and some of them practiced it. They included Ali bin Abu Talib, Sa'ad ibn Abi Waqqas, Abu Ayyub al-Ansari, Zaid ibn Thabit, Jabir ibn Abdullah, Abdullah ibn Abbas, Hasan ibn Ali and Abdullah bin Masud. However, it is worth noting that some

who tries to be too strict in matters of religion will have his purpose defeated Therefore, be on the right path, as in your morning course, your evening course and in your night journey"

${ }^{7}$ Qur'an 33:36 says: "It is not fitting for a believer, man or woman, when a matter has been decided by Allah and His Messenger, to have any opinion about their decisions. If anyone disobeys Allah and His Messenger, he is indeed on a clearly wrong path.

${ }^{8}$ Sahih Muslim is the second most authoritative and authentic book (source) of Hadith after Sahih al-Bukhari. The others are Sunan Abu Dawud, Sunan Al-Tirmidhi, Sunan An-Nasai and Sunan Ibn Majah. The six collections are referred to as Al-Sihaha Sita (The six canonical collections). Other books of hadith include the Muwatta of Imam Malik and Musnad of Ahmad ibn Hanbal.

${ }^{9}$ Companions of the Prophet, (Arabic Șahāabah or Aṣ̣āa) were the first generation of Muslims who were followers of Prophet Muhammad (Pbuh); they had personal contact with him and were therefore eyewitnesses of the Prophet's life. In Sunni Islam, the Companions were the most important sources of Hadith. 
Companions disliked al- 'Azl, for example, Umar bin Khattab, Uthman bin Affan and Abdullah bin Umar [4].

Muslim scholars from various schools of Islamic law ${ }^{10}$ concur that al- 'Azl is permissible with a wife's consent [5]. The popular view from the Hanafi School of law is that al'Azl is not permitted without the wife's consent [6]. While according to the Shafi'i School, al- 'Azl should be freely practiced without the wife's consent. Scholars of the Maliki School opine that, "no man has the right to practice al- 'Azl without the wife's consent [2].

Proponents of family planning cite verses on predestination (qadr) and reliance on Allah (tawakkul) ${ }^{11}$ discussed later in the paper - used by the opponents of family planning to argue against use of contraceptives. They cite the Qur'an (3:159) in which Allah advice the Prophet to rely on Him" to argue that taking precautionary measures is not disobedience to Allah [6]. They support their argument by quoting an explanation from Caliph Umar (the second caliph - successor to Muhammad (Pbuh) - of Islam who said: "reliance on Allah means to plant the seeds on the earth, then trust in Allah for a good crop". From this explanation, advocates of family planning posits that the use of contraceptives is only a means whose results are in the hands of Allah, which implies it could fail or succeed if Allah wishes [2].

Proponents of family planning also respond to the issue raised by the opponents of family planning - brought out later in the paper - that equate contraception with infanticide (wa'd). They argue that wa'd occurs when a live born child is killed or buried alive or when a fetus is aborted. They sustain the argument that contraception simply foils pregnancy and involves no killing. To further support their assertion, they give the example of Ali (the fourth Caliph) who, in the presence of Caliph Umar and other Companions of the Prophet (Pbuh) denied that al- 'Azl is wa'd [1].

From the foregoing discussion, we conclude that according to the advocates of family planning modern temporary methods of contraception, such as the condom and diaphragm, with the same objective as al- 'Azl, that is to prevent conception, could be permitted [8]. However, Muslim legal scholars only recommend safe temporary methods of contraception and not the permanent methods such as tubal ligation and vasectomy. There should always be valid reasons for contraceptive use, which should not include egotistic ones such as preference for a particular sex [5].

\section{OPPONENTS OF FAMILY PLANNING IN ISLAM}

Opponents of family planning use the Qur'an and Hadith and their interpretations to rebut the arguments of the proponents of family planning. According to the opponents of family planning any practice that prevents pregnancy such as al- 'Azl is tantamount to infanticide, which the Qur'an ${ }^{12}$ condemns by warning poverty-stricken Muslims not to kill

\footnotetext{
${ }^{10}$ There are four schools of thought (Islamic law) for Sunni Islam Hanafi, Shafi'i, Maliki and Hanbali - and the Jafari School for Shi'a Islam. These schools differ only in interpretations and not in the principles of Islamic law

${ }^{11}$ Qur'an 63:11; 81:29; 60:4; 65:2-3.

${ }^{12}$ Qur'an 17:31 says: "kill not your children for fear of want we shall provide sustenance for them as well as for you. Verily the killing of them is a great sin (cf., Qur'an 6:151).
}

their children since Allah is the sustainer. To discourage contraception, opponents of family planning use the Qur'anic verses, which prohibit infanticide [1], [4],[6].

The opponents of family planning argue that the larger the number of Muslims and the higher their population growth rate, the greater their power. Majority of Muslims perceive that child is a gift of God hence, the practice of establishing large families. Islam attaches much importance to marriage and giving birth to many children [5]. Opponents of family planning claim that a large population is a religious command, a view supported by the Qur'an ${ }^{13}$ and Hadith ${ }^{14}$ [7]. Further, they claim that family planning is a program originating from the West and is therefore a conspiracy to reduce the number of Muslims and diminish their power [5].

Further, opponents of family planning argue that the use of contraceptives to control one's offspring is contrary to predestination (qadr), that is, not trusting in Allah's ability to provide for children, hence denying reliance on Him (tawakkul) [1]. They cite numerous verses from the Qur'an to support their opinion on predestination, provision (rizq) and reliance on Allah (tawakkul) ${ }^{15}$. They argue that if Allah wants a child to be conceived, family planning will not prevent it because everything hinges on $\mathrm{Him}$ as the Master of the Universe (81:29) [6]. Muslims should also rely on Allah for themselves, and their progeny as stated in Qur'an 60:4.

Opponents of family planning also cite the Qur'anic description of wives being a tilth (2:223) unto their husbands and that the objective of the relationship between the husband and the wife is the procreation of the human species. This opinion sustains the argument of procreation being the ultimate purpose of marriage so that the Prophet (Pbuh) can boast of the number of his followers before other nations [6].

\section{Somali Community's Response to Family PLANNING}

Culture influences family planning practices among the Somali Muslims. There is no exception to this for the Somalis of Dadaab refugee camps. Both primary and secondary sources reveal that some community members consider family planning to be against Somali culture [2]. The Somali community perceives procreation as the main purpose of marriage. Children are a great asset in marriage and therefore any attempt at birth control is considered unlawful and contrary to religious teachings as advanced by opponents of family planning [7]. Field research shows that the Somali community prefers to have as many children as possible. Oral response from a Somali mid wife attest to this:

According to Somali culture, one of the goals of marriage is to bear children. Once this has been instilled into one's mind at young age, when you get married or marry you will have to reproduce as many children as you can. Therefore, this cultural belief does not correspond with

\footnotetext{
${ }^{13}$ For example, Quran 16:72 says: "And Allah has made for you mates (and companions) of your own nature, and made for you, out of them sons and daughters and grandchildren".

${ }^{14}$ A hadith from Sunan Abu Dawud enjoins Muslims to: "Marry and multiply for I will make a display of you on the day of Judgement"

${ }^{15}$ On predestination (qadr) the Qur'an 81:29; 63:11; on provision (rizq) Qur'an 11:6; on reliance on Allah (tawakkul), 65:2-3.
} 
family planning and most Somalis find family planning methods as a way of slowing down reproduction.

The community prefers the male child than female probably because of some cultural and religious values ${ }^{16}$. Culture values many children as an economic asset especially sons for family honor and social functions where number of children were equated with power [7]. Hence, the Somali community consider the use of contraceptives as a foreign ideology, which promotes immorality among the youth [2]. They are equally opposed to family planning methods that lead to permanent infertility like vasectomy and tubal ligation. There are however exceptional cases which are allowed when the pregnancy has to be terminated when the life of the mother is in danger ${ }^{17}$.

Besides culture, Islamic teachings also influence family planning practices among the Somali Muslims [7]. This is captured in the remarks of a Somali male academician who noted that:

Islam is a religion that teaches its followers what to do and how to behave in every situation. It teaches its followers when it's acceptable to do family planning and when it's not; it teaches that unless in exceptional cases family planning is strictly/strongly and highly prohibited. Exceptional cases include among others when the life of the mother is in danger unless pregnancy is terminated ${ }^{17}$.

We could argue that the influence of Islam on family planning among the Somalis is derived from the two perspectives of family planning discussed earlier in the paper. These perspectives inform the response of the Somali community in general and Somali Muslims in Dadaab in particular, to family planning. According to oral response, those in favor of family planning argue that:

Islam influences family planning in positive way as it encourages a woman to breastfeed a baby for two years, and parents to give each child affection and necessities he (she) might need. For this to happen, a couple has to use family planning methods ${ }^{18}$.

The above remarks concur with the teachings of the Qur'an and Hadith and interpretation of Muslim scholars on breastfeeding and child spacing discussed earlier in this paper. Data from secondary sources shows that some Somali Muslims prefer breastfeeding, periodic abstinence and use of herbs as indigenous methods of spacing children as opposed to modern methods of family planning [7]. Some of the herbs that are used for family planning include the Malmal and Mrifil - from comnifora species. We do not have any scientific evidence to support our claims, but the community use the two herbs in the belief that they have gynecological values. For example, Malmal solvent solution is considered to have power to control sexual desires among adult males

\footnotetext{
${ }^{16}$ Qur'an 18:46 says in part: "Wealth and sons are allurements of the life of this world".

${ }^{17}$ Oral Informant: Abdullahi Ibrahim Farah, 12-4-2021.

${ }^{18}$ Oral Informant: Abass Nasri, 23-1-2021.
}

[2]. It is therefore popular among Sufi ${ }^{19}$ students on religious training as they are able to complete their studies without distractions of sexual desires, which may lead to sexual promiscuity [7].

Oral response confirms the use of al- 'Azl as a method that Somali couples use for child spacing as per the teachings of Islam: "Islam teaches couples methods for family planning and gives example of withdrawal method."18

The opponents of family planning among the Somali Muslims consider contraceptives or anything that prevents pregnancy like al- 'Azl to be equivalent to infanticide as forbidden by the teachings of Qur'an [7]. Indeed, some perceive the use of contraceptives to control one's progeny to be against the concept of predestination and provision and reliance on Allah as taught in the Qur'an ${ }^{20}$. This is a perspective beholden to the opponents of family planning discussed earlier which seems to carry favor with oral response. Arguing that Islam is against family planning, an oral respondent retorted that: "according to sharia a woman should not do family planning" 21 . Another male respondent cited some Qur'an verses $(11: 6 ; 2: 28)$ that present Allah as the creator and sustainer and verses that warn Muslims against killing their children for lack $(6: 151 ; 17: 31)$. He also referred to the hadith from Sunan Abu Dawud in which the Prophet Muhammad (Pbuh) will proudly display his big Umma (community) in the Day of Judgment ${ }^{17}$. The remarks from the two respondents reflect the perspectives of the opponents of family planning.

\section{The Link Between FAMily PlanNing AND PREFERENCE FOR TBA}

Opposition to family planning is linked to preference of TBAs to hospitals. Oral response reveals that there is a perceived fear of having the pregnant mothers subjected to contraceptives if they deliver their babies in hospitals. This prompts the Somali Muslims in Dadaab refugee camps to prefer TBAs to hospitals. A Save mother (refugee midwife) observed: "They believe if they deliver in hospitals, they will be injected with some medicine that will make them family plan... if we inject them to stop bleeding, they think we are injecting them with family planning ${ }^{22}$. This observation shows one of the reasons for the preference of TBAs to midwives in hospitals. Another oral respondent who links the preference of TBAs to hospitals due to the fear of family planning notes that:

Having TBAs around in Somali community gives couples and family the inner peace knowing their wives would be in safe hands while they deliver; thus, largely giving way for couple to get as many children as they can without fear of being subjected to family planning ${ }^{18}$.

The above response affirms the assertion that there is link between family planning and the preference for TBAs among

\footnotetext{
19 Sufism is the mystical dimension of Islam. Sufis (Muslim mystics) emphasize on the importance of the inner development of the individual and his personal experience of God.

${ }^{20}$ Qur'an 81:29; 63:11; 11:6; 65:2-3.

${ }^{21}$ Oral Informant: Yusuf Ali, 10-12-2020.

${ }^{22}$ Oral information from a Save mother 10-12-2020.
} 
the Somali community of Dadaab refugee camps.

\section{CONCLUSION}

This paper has examined family planning as a determining factor in preference to TBAs among Somali Community in Dadaab Refugee Camps, Kenya. First, the paper explores family planning in Islam and shows that there are two perspectives: proponents of family planning and opponents of family planning. The paper has explored both perspectives, both of which use the Qur'an, the Hadith and their interpretations to buttress their arguments either for or against family planning in Islam. In regard to the proponents of family planning, we can conclude that Muslims could use modern temporary methods of family planning, and not the permanent methods to prevent conception. On the other hand, opponents of family planning argue that it is contrary to the teachings of Islam.

Secondly, through secondary data, the paper reveals that Somali culture and Islamic teachings influence family planning practices among Somali Muslims. These findings concur with the fieldwork survey, which revealed that Somali Muslims in Dadaab refugee camps are either for or against family planning. Those in favor of family planning cite the Islamic teachings to show that Islam is not against the practice. Conversely, the opponents of family planning argue that Somali culture and the teachings of Islam are against family planning. Therefore, we can conclude that, there is evidence to postulate that the two perspectives of family planning in Islam inform the beliefs and practices of the Somali community on family planning. However, in this discourse on family planning, it is apparent that the opponents of family planning hold sway visa-a-vis the proponents of family planning. Opposition to family planning, therefore, is linked to the Somali community's preference for TBAs to hospitals for expectant mothers. This is because there is a perceived and attendant fear that pregnant mothers who deliver their babies in hospitals could be subjected to contraceptives.

\section{RECOMMENDATIONS}

The paper draws a conclusion based on the secondary and oral data. Therefore, we propose the following recommendations:

The Somali community in Dadaab could be enlightened further on Islam's teachings on family planning. There is need for more active participatory role of community leaders (sheikhs, imams and leaders of local mosques) in educating the people on Islam's teachings on family planning. This could be done through the use of available Islamic institutions such as hospitals and schools to sensitize the community by emphasizing the benefits of child spacing to the mother, children, family and the community as a whole, instead of emphasizing on family planning.

There is need to build other family structures that will keep women engaged outside of the home as a means of making them see the need of not having many children because of childcare demands. Training and sensitization on child spacing should target the men who are the main decision makers in the Somali community.

There is need for empowerment of women through education institutions both in the formal and informal curriculum, e.g., topics on family-life education. Empowerment forums could also be conducted through social institutions targeting men and women separately.

There is need to enhance the government and stakeholders' role in helping the community appreciate by getting clear cultural and health perspectives on the importance of family planning. This could be done through a consultative engagement by all stakeholders with the view of coming up with a comprehensive integrated program of maternal healthcare into other services. This integrated program should target the mother and the child.

Finally, there is need to mainstream aspects of Islamic teachings on family planning in the training of midwives.

\section{ACKNOWLEDGMENT}

This is a revised paper that was presented at the International Congress on Midwifery and Maternal Health, May 19-20, 2021, Webinar. It was initially presented in the Conference on Digital Innovation \& Maternal Health Care for Migrant Mothers at Daadab Refugee Camp, Kenya, held on $3^{\text {rd }} \& 4^{\text {th }}$ February 2021 , Kenyatta University, Nairobi Kenya. The Conference was part of the ongoing research by researchers from Kenyatta University (Kenya) and New Castle University (UK) on Digital Innovation \& Maternal Health Care for Migrant Mothers Network. I acknowledge my co-investigators (Josephine Gitome, Jennifer Bagelman, Muthoni Mainah, Jacqueline M. Kituku, Teresa Mwoma and Priscilla Ndegwa), the Conference sponsors and organizers, and the feedback and input of the participants of the Conference.

\section{REFERENCES}

[1] A. R. Omran, Family Planning in the Legacy of Islam, London: Routledge, 1992.

[2] The Holy Qur'an, Text, Translation and Commentary by Abdullah Yusuf Ali. New Revised Edition. Maryland (USA), Amana Corporation.

[3] A. Sheraz and R. Zafar, "Islam and Family Planning: Perceptions and Practices (A Pilot Study in Sialkot and Chakwal Districts)," National Institute of Population Studies Islamabad, 2010.

[4] I. A. Hafsa, "Factors Affecting the Practice of Family Planning among Muslims. A Case Study of Majengo, Nairobi, Kenya”. MA in Religious Studies (Unpublished), University of Nairobi, 2015.

[5] A. Sheik, "Muslim Principles on Family Planning" MA (Islamic Studies) (Unpublished): University of Johannesburg. Retrieved from https://ujdigispace.uj.ac.za (Accessed: 15 January 2021), 1995.

[6] S. H. Abdi, "The Response of the Somali Muslim community to Modern Family Planning Practices in Garissa District". Master of Arts (MA Unpublished) Kenyatta University, 1999.

[7] V. Mishra, "Muslim/Non-Muslim Differentials in Fertility and Family Planning," Population and Health Series no. 112, 2004. 